\title{
POTENSI RADIKALISME DI SEKOLAH Studi Terhadap Buku Pendidikan Agama Islam Sekolah Dasar
}

\author{
RADICALISM POTENTIAL IN SCHOOL \\ Study Islamic Education Books in Primary Schools
}

\author{
Moh. Hasim \\ Balai Litbang Agama Semarang \\ Jl. Untung Suropati Kav. 70 Bambankerep Ngaliyan Semarang \\ Telp. 024-7601327 Fax. 024. 7611386 \\ Email: hasimlitbang@yahoo.co.id
}

\begin{abstract}
This study is motivated by the rampant violence among students. Islamic Education (PAI) as part of character education is seen to give $a$ hand in influencing students' attitudes and actions. This study aims to answer the question on how to shape the potential radicalism in the material books of PAl for Elementary Schools. Through qualitative approach with library research method, the study found the value of radicalism in the Islamic education material. The radical value which may affect the attitude of the students is the attitude of religious militancy driven by the spirit of jihad and towards other group / faiths, as well as narrow religious understanding.
\end{abstract}

Keywords: Radicalism, Pluralism, Islamic Education, Elementary School

\section{PENDAHULUAN}

Akhir-akhir ini, dikalangan remaja usia sekolah muncul bentuk kenakalan remaja yang mengarah pada tindak kekerasan. Beberapamediamenampilkanaksikekerasan yang dilakukan oleh remaja, seperti aksi

\begin{abstract}
Abstrak
Penelitian ini dilatar belakangi oleh maraknya tindak kekerasan yang dilakukan oleh para pelajar. Pendidikan Agama Islam (PAl) sebagai bagian dari pendidikan karakter dipandang ikut memberikan andil dalam mempengaruhi sikap dan tindakan siswa. Penelitian ini dimakudkan untuk menjawab permasalahan bagaimana bentuk potensi radikalisme dalam materi buku Ajar PAI Sekolah Dasar. Melalui pendekatan kualitatif dengan metode library recearch, penelitian ini menemukan adanya nilai radikalisme dalam materi pembejaran pendidikan Agama Islam di Sekolah Dasar. Nilai radikal yang dapat mempengaruhi sikap siswa yaitu sikap militansi keagamaan, yang didorong oleh ajaran jihat dan anti terhadap kelompok/ penganut agama lain, serta pemahaman keagamaan yang sempit.
\end{abstract}

Kata Kunci: Radikalisme, Pluralisme, Pendidikan Agama Islam, Sekolah Dasar,

penyiraman air keras di bus sekolah, bentrok antar pelajar atau perkelahian antar pelajar yang mengakibatkan hilangnya nyawa, aksi brutal remaja dalam geng motor, keterlibatan remaja dalam berbagai tindak kejahatan obat-obat terlarang, dan termasuk

Naskah diterima 29 Juni 2015. Revisi pertama, 15 Juli 2015. Revisi kedua, 21 Juli 2015 dan revisi terahir 29 Agustus 2015 
pula kekerasan remaja yang didasari oleh pengaruh sikap radikal dalam beragama.

Hasil survei Lembaga Kajian Islam dan Perdamaian (LKIP) selama Oktober 2010 hinggaJanuari2011jugamenunjukkanbahwa 49 persen siswa di Jabodetabek (Jakarta, Bogor, Tanggerang dan Bekasi) cenderung setuju menempuh aksi kekerasan untuk menyelesaikan masalah agama dan moral. ${ }^{1}$ Lebih ironisnya, menurut pandangan Ketua Komisi Perlindungan Anak Indonesia (KPAI) bahwa kekerasan yang dilakukan remaja khususnya siswa usia sekolah didasari oleh keterlibatan ajaran agama yang diberikan. Sekolah disenyalir telah mengajarkan intoleransi dan mengarahkan siswa untuk memiliki fanatisme terhadap ajaran agama tertentu. Indoktrinasi pendidikan agama terjadi disemua level pendidikan melalui kegiatan yang sistematis, dan anak-anak telah menjadi korban. ${ }^{2}$

Maraknya kasus kekerasan dengan melibatkan anak usia sekolah, menandakan bahwa perilaku bermoral atau akhlak siswa sedangdalamkondisiyangmemprihatiankan. Akhlak sebagai pengendali perilaku telah sirna dari kepribadian siswa, sehingga perilaku anak menjadi tidak terkontrol. Anak tidak lagi mampu membedakan mana tindakan yang bermoral dan mana yang tidak. Nilai-nilai kemanusiaan, penghargaan terhadap hak individu lain, penghormatan terdapat orang lain, rasa saling menyayangi tidak lagi menjadi pedoman dalam berbuat dan bertingkah laku.

${ }^{1}$ Nastiti Cayono. 2015. Ancaman Radikalisme Pada Dinamika Kehidupan Generasi Muda. www.compasiana. com.

${ }^{2}$ Voaindonesia. 2012. KPAI Desak Pemerintah Atasi Radikalisme Agama. www.voaindonesia.com.
Disadari atau tidak, bahwa pendidikan agama memberikan peran penting dalam membentuk kepribadian siswa. Akan tetapi secara kuantitatif, jumlah jam pengajaran pendidikan agama mendapatkan porsi sangat kurang memadai, dan dengan materi pendidikan agama yang lebih menekankan pengetahuan dari aspek kognitif semata. Akibatnya siswa tidak memikili kesempatan untuk mempraktekkan pendidikan agama yang mereka peroleh melalui perilaku keseharian di sekolah, dengan pengawasan, pengarahan dan evaluasi seorang guru.

Dilihat dari sisi kurikulum, materi PAI yang selama ini diajarkan pada siswa perlu juga di tengok kembali. Kurikulum sebagai acuan dalam pembelajaran berisi pedoman materi yang akan disampaikan kepada peserta didik. PAI sebagai sumber ajaran moral bagi siswa adalah patron nilai-nilai positif. Materi pendidikan agama diyakini mengandung kebenaran, akan menjadi kontrol perilaku. Oleh karena itu, maraknya tidak kekerasan yang dilakukan siswa usia sekolah yang mengarah pada bentuk radikalisme beragama, patut menjadi dasar keraguan, dugangan tidak terserapnya nilai-nilai agama secara baik. Sehingga merebaknya kekerasan yang mengarah pada tindakan radikal dikalangan pelajar, perlu di tindaklanjuti dengan upaya untuk melakukan telaah kritis terhadap buku ajar Pendidikan Agama Islam.

Upaya meninjau kembali materi pendidikan agama harus dimulai dari tingkat sekolah dasar. Karena pada pendidikan dasar, anak belum memiliki kemampuan menalar secara baik, dan dengan mudah menyerap apa saja informasi pengetahuan yang mereka peroleh, termasuk indoktrinasi ajaran agama yang kurang sesuai nilai- 
nilai kebebasan dan terbukaan beragama. Bertolak dari alasan tersebut, maka penelitian tentang buku ajar PAI Sekolah Dasar sangat penting dilakukan. Upaya ini dimaksudkan agar materi pengajaran pendidikan agama terbebas dari muatan ajaran yang melegalkan tindakan kekerasan melalui ideologi radikal.

Deradikalisasi potensi pendidikan keagamaan yang bersumber dari ajaran agama di sekolah, perlu untuk dilakukan. Sekecil apapun potensi kekerasan yang bersumber pada ajaran agama perlu untuk digantikan dengan nilai-nilai moral yang menghargai dan menghormati perbedaan keyakinan, melalui internalisasi pandangan multikultural sebagaimana diharapkan oleh tujuan pembangunan pendidikan di Indonesia.

Permasalahan yang diajukan dalam penelitian ini yaitu, bagaimana bentuk potensiradikalisme dalam materipendidikan Agama Islam di Sekolah Dasar. Oleh karena itu, penelitian ini dimaksudkan untuk mengetahui bentuk radikalisme yang ada dalam buku Pendidikan Agama Islam (PAI) yang diajarkan di Sekolah Dasar. Penelitian ini akan sangat bermanfaat sebagai bentuk telaah kritis terhadap buku teks PAI yang menjadi bahan pengajaran untuk menanamkan nilai-nilai pendidikan moral keagamaan disekolah agar sesuai dengan tujuan pendidikan nasional. Sehingga upaya ini dapat bahan pertimbangan pemerintah untuk melakukan upaya pengembangan kurikulum PAI sesuai dengan dinamika perubahan sosial masyarakat dan kebutuhan penanaman moral yang humanis dalam beragama.

\section{Kerangka Teori}

Menurut kamus besar bahasa Indonesia, radikalisme berakar dari kata radikal yang memiliki beberapa pengertian yaitu: a). Paham atau alian yang radikal dalam politik, b). paham atau aliran yang menginginkan perubahan atau pembaharuan sosial dan politik dengan cara kekerasan atau drastis, c). Sikap ekstrem dalam aliran politik. Sedangkan kata radikal sendiri dimaknai sebagaikatasifatyang memilikimakna secara menyeluruh, habis-habisan; perubahan yang amat keras menuntut perubahan (undang-undang pemerintah dsb), maju dalam berfikir dan atau bertindak. ${ }^{3}$

Pengertian baku terkait dengan definisi radikalisme Di antara para pemikir belum ada titik temu yang mampu memuaskan semua kalangan. Kalau dilihat dari makna dasar kata radikal dan atau radikalisme adalah konsep yang netral, tidak mengandung konotasi negatif. ${ }^{4}$ Akan tetapi dalam pemikiran sosial keagamaan, radikalisme sering disandingkan dengan gerakan revivalisme dan fundamentalism. Revivalisme yaitu sebuah istilah yang digunakan untuk menggambarkan tren kebangkitan Islam secara umum dilihat dari sisi pemikiran dan memiliki makna dengan konotasi positif. Sedangkan fundamentalisme muncul karena diilhami oleh semangat dari penganut kristen konservatif untuk mencari pokokpokok ajaran fundamental, yang menjadi dasar penting sebuah agama.

\footnotetext{
${ }^{3}$ Departemen Pendidikan dan Kebudayaan.1989. Kamus Besar Bahasa Indonesia. Jakarta: Balai Pustaka, h. 718-719.

${ }^{4}$ Wahid Khozin. 2013. "Sikap Keagamaan dan Potensi Radikalisme Agama Mahasiswa Perguruan Tinggi Agama". Edukasi Jurnal Pendidikan Agama dan Keagamaan, 11 (3): h.294.
} 
Fundamentalisme ini kemudian digunakan penganut agama untuk memahami persoalan sosial, politik, maupun hukumhukum syariah. Akan tetapi, konotasi positif makna fundamentalisme ini kemudian dirusak oleh media (pers) Barat. Fundamentalisme digunakan oleh para pemikir barat untuk memberikan gambaran gerakan kebangkitan Islam kontemporer dengan maksud sebagai sikap radikal yang mengarah pada tindakan terorisme. Fundamentalisme dimaknai sebagai neofundamentalis yaitu gerakan Islam politik yang berkonotasi ekstrem, militan dan non toleran serta anti barat/Amerika, dan lebih dekat dengan teorisme. ${ }^{5}$

Pada dataran konsep ideologis, radikalisme agama adalah cara pandang yang melihat bahwa keyakinan keagamaan sebagai sesuatu yang memiliki kebenaran mutlak dan harus ditegakkan dalam praktek sosial. Radikalisme beragama memandang bahwa untuk menegakkan agama dibutuhkan sebuah upaya dalam bentuk konsep amar ma'ruf nahi munngkar tanpa ada kompromi. Dalam dataran praktek, radikalisme beragama membenarkan caracara kekerasan unntuk mewujudkan sebuah tatanan ideal kehidupan bermasyarakat berdasarkan agama. Radikalisme agama memandang bahwa pemahaman terhadap doktrin agama harus dipahami secara apa adanya(tekstual) tanpa melihat konteks sosial, dan amalkan, dipatuhi tanpa ada

${ }^{5}$ Richard T Antoun. 2001.Understanding fundamentalism: Christian, Islamic, and Jewish. Walnut Creek. CA: Alta Mira Press; Muhammad Imarah. 1999. Fundamentalisme Dalam Perspektif Barat dan Islam. Terj. Abdul Hayyie al-Kattani. Jakarta: Gema Insani Press. h. 11-21. Baca juga: Endang Turmudzi dan Riza Sihbudi. 2005. Islam dan Radikalisme di Indonesia. Jakarta: LIPI Press. bantahan, modifikasi, atau penyesuaian dengan kondisi sosial budaya masyarakat. ${ }^{6}$

Dalam konteks radikalisme Islam, alZastrouw membagi gerakan radikal Islam kepada dua tipologi: Pertama, gerakan Islam radikal-kritis. Gerakan ini muncul karena adanya tekanan sosial, kesewenangwenangan, dan ketidakadilan sosial yang dilakukan kolonial terhadap golongan pribumi. Kedua, Gerakan Islam RadikalFundamentalis yaitu gerakan radikal yang ideologis, anti dialog, eksklusif dan tidak mengenal kompromi, tidak memberikan kesempatan dan ruang pada tradisi dan nilainilai lokal, karena dianggap membelokkan ajaran Islam (bid'ah). ${ }^{\text {? }}$

Kemudian terkait dengan ciri-ciri gerakan radikal, Yusuf al-Qordawi ${ }^{8}$ (2001) mengungkapkan bahwa kelompok fundamentalis radikal yang fanatik dapat dicirikan oleh beberapa karakter, sebagai berikut: pertama, Memberikan klaim kebenaran tunggal pada keyakinan keagamaan tertettu. Sehingga kelompok fundamentalis radikal cenderung dengan mudah menyesatkan kelompok lain yang tak sependapat. Mereka

${ }^{6}$ Tim Setara Intitute. 2010. Wajah Para "Pembela" Islam: Radikalisme Agama dan Implikasinya terhadap Jaminan Kebebasan Beragama/Bekeyakinan di Dejabotek dan jawa Barat. Jakarta: Pustaka Masyarakat Setara; Hamami Zada. 2004. Islam Radikal: Pegulatan Ormas-Ormas Islam Garis Keras di Indonesia. Jakarta: Teraju. Baca juga: Zuly Qodir. 2014. Radikalisme Agama di Indonesia. Yogyakarta: Pustaka Pelajar; Wahid Khozin. 2013. "Sikap Keagamaan dan Potensi Radikalisme Agama Mahasiswa Perguruan Tinggi Agama". Edukasi Jurnal Pendidikan Agama dan Keagamaan, 11 (3): 294.

7 Al-Zastrouw Ngatawi. 2006. Gerakan Islam Simbolik: Politik Kepentingan FPI. Yogyakarta: LkiS.

8 Yusuf Al-Qordawi. 2001. Ekstrimisme Dalam Wacana Islam, Islam Liberal, Pemikiran Islam Kontemporer Tentang Isu-Isu Global. Charterkhurzman (ed). Jakarta: Paramadina. 
memposisikan diri seolah-olah sebagai "nabi" yang diutus oleh Tuhan untuk meluruskan kembali manusia yang tak sepaham dengannya.

Kedua, Cenderung mempersulit agama dengan menganggap ibadah sunnah seakanakan wajib dan hal yang makruh seakanakan haram. Berupaya mencontoh atau pengembalikan ajaran agama sesuai dengan perilaku yang diconothkan oleh nabi, tanpa melihat konteks perubahan sosial di masyarakat. Sebagai contoh ialah fenomena memanjangkan jenggot dan meninggikan celana di atas mata kaki. Bagi mereka ini adalah hal yang wajib.

Ketiga, Mereka yang fundamentalis radikal kebanyakkan mengalami overdosis agama yang tidak pada tempatnya. Misalnya, dalam berdakwah mereka mengesampingkan metode gradual, "step by step", yang digunakan oleh Nabi. Sehingga bagi orang awam, mereka cenderung kasar dalam berinteraksi, keras dalam berbicara dan emosional dalam menyampaikan.

Keempat, Mudah mengkafirkan orang lain yang berbeda pendapat. Mereka mudah berburuk sangka kepada orang lain yang tak sepaham dengan pemikiran serta tindakkannya. Mereka cenderung memandang dunia ini hanya dengan dua warna saja, yaitu hitam dan putih.

Dari sifat-sifat dasar pemahaman agama maka sikap radikal muncul dari pemahaman keagamaan eksklusif, yaitu pemahaman keagamaan yang menganggap bahwa tidak ada kebenaran agama yang lain, kecuali keyakinan keagaman yang bersangkutan. Keyakinan keagamaan adalah absolud, yang tertinggi dan muntak. Kelompok atau penganut agama yang berada diluar keyakinannya dianggap sebagai kelompok yang salah atau "kafir". Sikap eksklusif ini menumbuhkan sikap tidak diakuinya kebenaran lain diluar kebenaran keyakinan agamanya.

Pemahaman eksklusif memberikan imbas pada pola dakwah yang dilakukan, yaitu ajaran dari teks suci (kitab) harus disebarkan (dakwah) dengan cara-cara radikal sebagai bentuk pengorbanan kepada Tuhan. Buntutnya pemaknaan tentang jihat adalah suatu yang indah. Bahkan sebagai bentuk pengabdian pada Tuhan, seorang yang mengikuti pafam radikal tidak segan-segan mengorbankan harta benda dan nyawa, sehingga berbagai cara dapat dilakukan untuk mewujudkan perintah kebenaran dari Tuhan. ${ }^{9}$

Oleh karena itu, dapat di garis bawahi bahwa apa yang dimaksud radikalisme yaitu sikap keras dalam menerapkan ajaran agama tanpa mempedulikan cara pandang agama lain. Radikalisme berupaya memperjuangkan keyakinan keagamaan yang dianutnya dilakukan dengan tanpa kompromi dan bila perlu dilakukan dengan cara kekerasan dan anarkisme. Agama dipahami secara parsial, teks-teks agama dipisahkan dari konteksnya, dan akibat dari pengalaman ajaran agama kering dari nilainilai spiritualitas.

\section{Metode Penelitian}

Penelitian ini menggunakan pendekatan kualitatif yaitu dengan menggunakan studi pustaka (library recearch), dengan

${ }^{9}$ Alwi Shihab. 1997. Islam Inklusif Menuju Sikap Terbuka Dalam Beragama.: Penerbit Mizan; Baca Juga: Mun'in A. 2003. Membendung Militansi Agama: Iman dan Politik Dalam Masyarakat Modern. Jakarta: Erlangga. 
pokok kajian pada buku-buku pendidikan agama Islam yang digunakan di sekolah dasar di Daerah Istimewa Yogyakarta. Data diperoleh dengan cara mendatangi mendatangi dan menanyakan kepada guru Agama Islam di sebagian Sekolah Dasar Negeri di Yogyakarta, tentang buku acuan pembelajaran Pendidikan Agama Islam yang di gunakan.

Penggalian data difokuskan pada 12 buku pendidikan agama Islam yang digunakan di Sekolah Dasar Negeri di Yogyakarta yang dikeluarkan oleh 2 penerbit utama. Dalam artikel ini identitas penerbit dirahasiakan untuk menjaga privasinya, yaitu :

- Buku Pendidikan Agama Islam 1, Penerbit A, No ISBN 978-XXX-09X928-1-5

- BukuPendidikan Agama Islam 2, Penerbit A, No ISBN 978-XXX-09X928-2-2

- BukuPendidikan Agama Islam 3, Penerbit A, No ISBN 978-XXX-09X928-3-9

- Buku Pendidikan Agama Islam 4, Penerbit A, No ISBN 978-XXX-09X928-4-6

- Buku Pendidikan Agama Islam 5, Penerbit A, No ISBN 978-XXX-09X928-5-3

- Buku Pendidikan Agama Islam 6, Penerbit A, No ISBN 978-XXX-09X928-6-0

- Buku xxxxx Agama Islam untuk Sekolah Dasar kelas I, Penerbit B,

- $\quad$ No ISBN 978-XXX-01X-013-3

- Buku xxxxx Agama Islam untuk Sekolah Dasar kelas II, Penerbit B,

- No ISBN 978-XXX-01X-018-8

- Buku xxxxx Agama Islam untuk Sekolah Dasar kelas III, Penerbit B,

- No ISBN 978-XXX-01X-015-7

- Buku xxxxx Agama Islam untuk Sekolah Dasar kelas IV, Penerbit B,
- $\quad$ No ISBN 978-XXX-01X-016-4

- Buku xxxxx Agama Islam untuk Sekolah Dasar kelas V, Penerbit B,

- No ISBN 978-XXX-01X-017-1

- Buku xxxxx Agama Islam untuk Sekolah Dasar kelas VI, Penerbit B,

- $\quad$ No ISBN 978-XXX-01X-018-8

Data yang diperoleh dengan menelaah melalui membaca secara seksama. Data yang diperoleh kemudian dicacat dan di kelompokkan sesuai dengan tema. Data yang mengandung nilai-nilai moral ini kemudian di kembangkan dalam telaah analisis kritis untuk melihat materi pelajaran PAI yang mengandung muatan ajaran radikal. Pendidikan agama yang dipandang berpotensi nilai-nilai radikalisme yaitu mengajarkan sikap militansi beragama yang dibarengi dengan penolakan terhadap ajaran agama lain; mengunakan cara-cara kekerasan dalam berdakwah seperti memberikan labelisasi kafir kepada kelompok diluar keyakinannya, menempatkan jihat sebagai jalan terakhir dalam menegakkan ajaran Tuhan; tidak menghormati perbedaan keyakinan dan menerbarkan kebencian pada kelompok agama lain, dan memberikan klaim atas kebenaran ajaran agama tertentu.

\section{HASIL DAN PEMBAHASAN}

Sesuai dengan tujuan pendidikan nasional yaitu pendidikan nasional memiliki orientasi menciptakan perserta didik agar menjadi manusia yang beriman dan bertakwa kepada Tuhan Yang Maha Esa berakhlak mulia, sehat, berilmu, cakap, kreatif mandiri, dan menjadi warga negara 
yang demokratis serta bertanggungjawab (UU Sisdiknas). Untuk mewujudkan tujuan tersebut tentu bukan hal yang mudah, tetapi membutuhkan upaya dan usaha keras semua pihak baik unsur masyarakat maupun pemerintah.

Pendidikan sangat dibutuhkan oleh peserta didik untuk membekali kemampuan dalam bentuk ketrampilan, pengetahuan dan nilai-nilai. Ketrampilan dan pengetahuan digunakan untuk memenuhi kebutuhan hidupnya, sedangkan pemahaman akan nilai-niai sangat berguna untuk kontrol perilaku. Dengan memahami nilai baik atau buruk seorang anak dapat memilih jalan hidup yang bermartabat, tidak membabi buta, menghalalkan segala cara.

Dalam dunia pendidikan terkait studi perilaku manusia, W Stern dengan teori hukum konvergensi, menyebutkan perkembangan perilaku manusia ditentukan oleh dua faktor secara bersamaan, yaitu faktor internal berupa sifat-sifat pembawaan yang diperoleh secara alami dan faktor lingkungan tempat tumbuh kembangnya. ${ }^{10}$

Terkait dengan maraknya tindakan radikalisme beragama dikalangan siswa tentu tidak semata-mata disebabkan oleh faktor tunggal. Radikalisme tidak serta merta muncul karena sifat pembawaan lahir, atau karena kesalahan dalam proses pendidikan agama. Radikalisme adakarena sebab yang multi dimensi seperti karena pengaruh persoalan politik, ekonomi, ketidakadilan

${ }^{10}$ Ngalim Purwanto. 2003. Ilmu Pendidikan Teoretis dan Praktis. Bandung: PT Remaja Rosdakarya. h. 58-61. sosial, dan dimungkinkan karena pengaruh ideologi/faham keagamaan global. ${ }^{11}$

Sisi pendidikan merupakan bagian kecil dari faktor yang membentuk perilaku seoarang anak. Sehingga, seorang anak meski tidak mendapatkan pendidikan agama yang memadai, tetapi hidup dalam lingkungan yang baik, maka dapat dimungkinkan akan memiliki perilaku yang baik. Demikian juga, dengan daya dukung lingkungan yang baik, memungkinkan siswa yang memiliki naluri kekerasan dapat di ubah kerarah sikap yang lebih toleran, menghargai perbedaan, lembut, dan memiliki akhlak yang mulia.

Oleh karena itu, mencari sumber munculnya gerakan radikal dalam beragama dengan hanya melihat pada sumber bacaan siswa merupakan langkah kecil dari upaya untuk melihat sebuah potensi kemungkinan munculnya tindakan radikal dari sebab di satu sisi saja. Pada sisi yang lain tentu masih banyak faktor yang bisa mempengaruhi sesorang anak melakukan sebuah tindakan kekerasan atas nama agama. Bagaimana peran guru dalam memberikan penjelasan, peran orang tua, pengaruh lingkungan pertemanan, dan juga pengaruh dari media innformasi lainnya, ikut menentukan sikap dan tindakan seorang anak.

Kalau dilihat secara teknis, Ketiga buku PAI yang dikeluarkan oleh penerbit dari hasil analisa peneliti, nampak telah memenuhi standar isi yang dikeluarkan oleh Kementerian Pendidikan Nasional. Oleh karena itu, secara formal, ketiga buku tersebut telah memenuhi tuntutan kurikulumyang ditetapkan oleh pemerintah. Akan tetapi, tema-tema materi yang di

${ }^{11}$ Muhammad Asfar, ed. 2003. Islam Lunak Islam Radikal. Surabaya: JP Press. h. 45-63. 
usung menunjukkan masih sebatas pada pengetahuan tentang ajaran agama yang membangun kesalehan personal seperti materi tentang fiqh ibadah, kemanpuan baca dan tulis al-qur'an, pengetahuan tentang ajaran tauhid, sejarah Islam, dan akhlak. Sementara itu tema-tema akhlak sendiri masih sangat universal, belum mengarah pada pembentukan kepribadian yang plural dan menghormati perbedaan keyakinan agama. Tema-tema akhlak yang disampaikan dalam buku PAI secara umum yaitu bertemakan tentang sabar, ikhlas, hemat, tekun dll.

Nilai-nilai moral yang sangat dibutuhkan dalam menghadapi radikalisme beragama yaitu bagaimana mensikapi perbedaan keyakinan sebagai sebuah berkah, yang diberikan Tuhan. Agama hadir tidak dalam rangka menciptakan perbedaan dan permusuhan, tetapi sebagai rahmat yang membangun jalan kedamaian. Ajaran moral keagamaan yang ditumbuhkan adalah untuk mengarahkan pemeluk beragama hidup berdampingan secara damai, bekerjasama dalam membangun kehidupan sosial. Tidak sebaliknya, menonjolkan pemahaman ajaran keagamaan tertentu secara doktrinal, memberikan klaim kebenaran sendiri, tidak mengakui kebenaran agama lain.

Menghadapi perubahan sosial dan tututan masyarakat saat sekarang ini, terutama dalam menghadapi maraknya aksi kekerasan dengan mengatasnamakan agama, Di antara ketiga buku tersebut masih syarat dengan muatan materi yang bisa memancing pemahaman agama yang kurang toleran. Potensi materi PAI SD yang dimungkinkan akan memancing pemahaman radikal dalam beragama Di antaranya :
Pertama, mengenalkan konsep kafir sebagai lawan dengan konsep muslim. Muslim diidentikkan dengan perilaku kebenaran yang mendapatkan ridlo dan pujian dari Tuhan. Sedangkan kafir adalah musuh Allah yang lebih pantas masuk dalam neraka. Muslim dan kafir dihadapkan pada sisi yang berlawanan tanpa ada penjelasan yang cukup. Sedangkan dalam ajaran Islam, konsepsi tentang kafir memiliki penjabaran yang sangat luas seperti Kafir zimmi, yaitu kafir yang wajib dilindungi.

Dapat dijadikan contoh misalnya, dalam buku Pendidikan Agama kelas lima penerbit A hal 6, dalam penjelasan surat Al-Kafirun disebutkan:

"sebagai arang Islam kita harus mengambil pelajaran bahwa kita tidak boleh menyembah selain Allah. Allah ialah Tuhan semesta alam, tidak ada sekutu baginya, tidak beranak dan tidak diperanakkan. Orang-orang kafir Quraisy akan masuk neraka selama-lamanya, karena berbuat syirik (musyrik). Yaitu menyekutukan selain Allah.

Kemudian dalam buku PAI, penerbit B kelas $\mathrm{V}$ hal 5 sebagai berikut:

"Surat ini diturunkan karena orang kafir membuat berhala dan menyembahnya, serta memaksa nabi untuk turut menyembah berhala yang mereka buat. Surat Al-Kafirun berisi tentang pernyataan bahawa Tuhan yang disembah Nabi Muhamamad SAW dan sahabatnya bukanlah apa yang disembah oleh orang kafir".

Pernyataan seperti tersebut tentu belum mengarah pada esensi penghormatan pada perbedaan keyakinan, tetapi justru lebih menekankan pada penilaian bahwa penyembahan terhadap esistensi Tuhan 
selain dalam konsep Allah adalah sesuatu yang salah dan pantas masuk neraka. Sehingga terminologi kafir bisa memicu atau memberikan pemahaman pada siswa akan adanya konsep permusuhan dengan orang berbeda keyakinan keagamaan, karena mereka tidak menyembah Allah. Akibatnya akan menimbulkan persepsi anak bahwa orang-orang yang berbeda agama, tidak layak mendapatkan kebahagiaan di surga, tetapi lebih pantas masuk neraka.

Konsep kafir ini akan membangun sebuah dasar permusuhan. Hal ini muncul ketika seorang anak menghadapi lingkungan pertemanan dengan orang lain yang beda agama. Anak tidak akan bisa menemukan dalam realitas sekarang, konsep penyambah berhala dalam pengertian patung-patung. Akan tetapi yang ditemukan adalah pemelukpemeluk agama lain yang nota bebenya adalah saudara-saudara mereka sendiri. Sedangkan orang yang tidak menyembah Allah termasuk melakukan perbuatan syirik, sama dengan orang-orang kafir yang hanya pantas masuk neraka.

Keteguhan dalam menyakini keimanan, tentu bisa dibenarkan dalam kacamata internal agama. Akan tetapi dalam membangun sikap hidup dalam ranah sosial, konsep kafir yang di terapkan pada institusi pendidikan sekolah dasar (bukan sekolah agama) akan menimbulkan perselisihan Di antara peserta didik. Karena lembaga pendidikan umum memungkinkan adanya peserta didik yang beda agama. Apa jadinya, seandainya seorang anak yang kritis menanyakan pada pemeluk agama lain mengenai Tuhannya, kemudian anak itu memberikan persepsi bahwa temannya itu adalah seorang kafir karena tidak menyembah Allah.
Kedua, memunculkan pertentangan ajaran antar agama. Pertentangan ajaran antar agama ini yang bersumber dari konsep kafir dan muslim, akan semakin menguat ketika materi pendidikan agama bertentangan dengan konsep-konsep agama lain. Seperti materi yang yang menjelaskan mengenai Nabi Isa. Bagi kalangan Islam menilai bahwa, Nabi Isa tidaklah mati disalib tapi diselamatkan oleh Allah dan akan diturunkan kembali kebumi sebagai Imam Mahdi.Pemahaman ini berbeda dengan umat Nasrani, mereka menyakini bahwa Isa telah mati sebagi bentuk tebusan terhadap dosa pengikut-pengikutnya. Dalam teks buku PAI terbitan A kelas 5 hal 36 disebutkan:

“Ajaran Isa pada dasarnya sama dengan Islam yaitu mempercayai tidak ada Tuhan selain Alllah dan Alah tidak beranak dan dipernanakkan...sewaktu pengikut nabi Isa a.s. masih 12 orang salah satu muridnya bernama Yahuda (Yudas Iskariat murtad). Yahuda bertekat akan membunuh Isa a.s. Ia ditunjuk sebagai pemimpin pembunuhan. Atas kehendak dan kekuasaan Allah swt. Yahuda wajahnya diubah serupa nabi Isa a.s ia ditangkap lalu di salin di bukit Golgota, sedangkan Nabi Isa a.s. diselamatkan oleh Allah swt.

Informasi yang sama juga ada pada buku B kelas 5 halaman 34.

Perbedaan padangan semacam ini jika tidak dijelaskan secara lebih luas- konteks pemahaman pluralisme-sesuai dengan pandangan masing-masing agama baik Islam mapun Nasrani, maka akan menumbuhkan sikap saling bermusuhan antar agama. Masing-masing agama akan memberikan klaim bahwa ajarannya yang paling benar, dan menurut pikiran sehat, tidak mungkin kedua-duanya benar. 
Benih-benih pertentangan masalah kematian Nabi Isa yang dipertentangkan ini sudah muncul. Dalam sebuah artikel yang dikelola oleh komunitas bloqer Kristen dengan judul Bagimu AgamamuBagiku Agamamku. Komunitas kristen ini menunjukkan sikap menolak terhadap konsep ini. Bagi mereka, Islam dipandang tidak konsisten, karena Islam masih dipandang mengurusi keyakinan orang lain dalam kisah nabi Isa. Dalam tulisan blog dengan jelas mereka menolak kisah Isa yang tertera dalam buku tersebut. Mereka menyebutkan:

“yang lucu lagi, dengan mengatakan bagimu agamamu dan bagiku agamaku mereka (peneliti :Islam ) mengatakan Yesus Kristus tidak disalib dan digantikan oleh seorang yang bernama Yahuda yang kita kenal dengan Yudas Iskariot. Kalimat tersebut diajarkan dalam pelajaran agama mereka ..." 12

Ketiga, memuat materi yang menggugah semangat militansi beragama secara sempit. Materi menumbuhkan sikap militansi beragama yang sempit bahkan yang mengarah pada semanngat jihat Di antaranya terdapat dalam kisah Dewi Masyitah. Materi tentang kepahlawanan Dewi Masyitah terdapat dalam pelajaran PAI kelas I Penerbit A. Dikisahkan Dewi Masyitoh adalah tukang sisir putri raja Firaun. Ketika Masyitoh sedang menjalankan tugasnya, secara tidak sengaja sisir yang digunakan terjatuh, dengan spontan dia menyebut asma Allah. Sejak itulah, keimanan Dewi Masyitoh dipertanyakan oleh Fir'aun, sang raja yang mengaku sebagai Tuhan. Fir'aun sangat murka, karena ada Tuhan lain

${ }^{12}$ http://www.sabdaspace.org. selain dirinya. Untuk mempertahankan keimanannya, masyitoh rela mati dalam bejana panas penuh minyak.

Kisah Masyitoh ini akan memberikan inspirasi pada siswa tentang semangat Jihat dalam membela kebenaran agama. Keyakinan agama adalah sesuatu yang final dan harus dipertahankan sampai titik darah penghabisan. Bisa saja semangat jihat dengan mengorbankan nyawa adalah sesuatu yang prinsip dalam ajaran agama. Akan tetapi dalam konteks sosial (kenyataannya) dalam negara pancasila ini tidak ada upaya untuk pemaksaan dalam menyakini sebuah keyakinan keagamaan.

Keempat, memuat materi tentang kisahkisah perang. PAI memberikan ulasan sejarah Islam tentang perang yang dilakukan para sahabat. Peperangan dilakukan dalam rangka perluasan wilayah kekuasaan, mengadili orang-orang yang murtad dan menumpas nabi-nabi palsu.Kisah perang terdapat pada buku PAI penerbit B Kelas V hal 94-95; Buku PAI Penerbit A kelas V hal 116.

Kisah-kisah peperangan ini akan memberikan rangsangan pada otak anak mengenal kekerasan dan pemusuhan. Apabila hal ini dilakukan tanpa ada penjelasan yang memadai, dan informasi ini diterima anak secara terus menerus, maka akan memimbulkan pemahaman bahwa kekerasan dapat dibenarkan dalam menyelesakan sebuah masalah, atau dalam rangka menegakkan syari'at Tuhan.

Kelima, mengenalkan konsep jihad. Jihad sebenarnya memiliki makna positif. Akan tetapi saat ini makna jihad telah bergeser kearah makna negatif, akibat dari trereotipe yang dibangun media dari pemberitaan 
tentang terorisme. Nabi sendiri pernah mengatakan bahwa sebenarnya jihad yang paling berat adalah jihad menahan hawa nafsu. Hal ini mengartikan bahwa jihat itu pada hakekatnya adalah melakukan perbuatan yang baik, tidak menurutkan hawa nafsu atau keinginan yang rendah dalam rangka mengikuti perintah Allah. ${ }^{13}$

Jihad dalam buku PAI SD ini, jihat digambarkan sebagi sebuah pengorbanan jiwa untuk kepentingan agama. Jihat tidak dimaknai secara luas, tetapi disempitkan menjadi pengorbanan diri untuk membela agama. Makna jihat seperti ini jelas tergambarkan dalam kisah sahabat Aswad yang tertulis dalam buku PAI penerbit A kelas 2 hal 44-45. Jihad diidentikkan dengan kematian atas nama agama.

Dalam buku tersebut disebutkan tentang kesahidan seorang budak yang bernama Aswad. Aswad adalah seorang pengembala kambing milik Yahudi.Dalam perang khubar, Aswad masuk Islam dan ikut membantu nabi dalam peperangan. Aswad gugur dalam pertempuran, dan ketika jenazahnya tergeletak bersama muslim yang gugur, nabi memalingkan muka melihat jenazah aswad. Para sahabat bertanya, "ya Rasulullah, mengapa anda membuang muka, melempar pandangan ketempat lain?" Nabi menjawab: "Kulihat Aswad sedang duduk bersanding dan bercengkrama dengan seorang bidadari yang menjadi istrinya, "Jawab Rasulullah tersipu.

Kisah aswad yang dalam kematiannya bertemu dengan bidadari sebagai istrinya akan mengingatkan pada istilah "pengantin" dalam kejadian terorisme beberapa tahun

${ }^{13}$ M Habib Chirzin. 2005. Penafsiran Rasyid Ridla dan Sayyid Quthb Tentang Jihad. Jakarta: Departemen Agama. h. 13-15. lalu. Para pelaku BOM sebagai pengantin dengan bangga menyiapkan dirinya untuk mati dengan keyakinan akan hidup bahagia di surga, mati sebagai syahid. Padahal dibalik kekejian yang mereka lakukan, terdapat orang-orang yang tidak berdosa ikut menjadi kurban.Tentu hal ini tidak bisa dibenarkan oleh ajaran agama.

Dengan penyajian materi tentang model jihad seperti itu, maka pemahaman ajaran agama seperti yang digambarkan pada cerita Dewi Masyitoh, dan sahabat Aswad, akan membawa pemahaman keagamaan siswa tentang perjuangan Islam dalam bentuk pengorbanan diri. Jihad dengan mengorbankan nyawa untuk menyebarkan agama seolah dapat dibenarkan dan akan mendapatkan pahala surga. Jihad diidentikkan dengan perang, kerelaan menyerahkan nyawa untuk perjuangan agama. Jihad tidak dimaknai sebagai upaya untuk menegakkan perintah allah dalam arti yang luas.

Konsep jihad inilah yang selama ini disalah gunakan untuk memberikan legalitas untuk membunuh kelompok lain agama. Tentunya bagi anak-anak pemberian materi jihad sangat riskan (rawan) dan bisa menumbuhkan benih-benih intoleransi/ radikalimse dalam beragama. Benih radikalisme itu akan terpupuk manakala sikap militansi dalam beragama (revivalis) ditempatkan pada posisi yang salah. Keberagamaan seseorang memang di tutut untuk tidak hanya sekedar manis dimulud, tetapi dibutuhkan sikap pengorbanan dan bukti nyata. Akan tetapi, militansi yang mengarah pada sikap fundamentalisme bisa dengan mudah dimasuki oleh faham radikal. 
Dan radikalisme merupakan pintu masuk menuju terorisme. ${ }^{14}$

Materi penghormatan perbedaan keyakinan ini sebenarnya juga ada dan jelas didalam buku Penerbit A kelas 5, yaitu ketika Nabi Muhamamd tidak memaksa pamannya Abu Tholib untuk beriman kepada Allah. Sangatlah disayangkan materi PAI yang sudah mengajarkan bentuk penghormatan pada agama lain masih bercampur dengan materi yang berpotensi membentuk kepribadian yang mendukung terhadap kekerasan dalam penegakkan kebenaran. Materi PAI Dalam Teks PAI Penerbit A Kelas V halaman 8 di sebutkan:

"Demikian contoh saling menghormati hak beragama satu sama lain. Nabi Muhammad saw. Pun tidak memaksa pamannya Abu Talib agar beriman kepada Allah dan memeluk agama Islam.

Oleh karena itu, penyajian materi pendidikan agama seperti surat al-Kafirun harus di imbangi dengan penjelasan pentingnya pemahaman Islam secara inklusif. Dalil Qur'an lakum dînukum waliadîn, dapat dijadikan dasar dalam memumbuhkan sikap beragama secara terbuka dengan saling menghormati, bukan menonjolkan berbedaan antara kafir dengan muslim. Selain itu, pemahaman adanya sikap hidup beragama secara multikultural, yaitu sikap bahwa keberadaan kita tidak lepas dari perbedaaan dengan kelompok lain. Perbedaaan-perbedaan ini adalah sebuah keniscayaan yang alami dan tidak mungkin untuk di paksaan. Sehingga masyarakat

${ }^{14}$ Tim Setara Institut. 2012. Dari Radikalisme Menuju Terorisme: Studi Relasi dan Transformasi Organisasi Islam Radikal di Jawa Tengah dan D.I. Yigyakarta. Jakarta: Pustaka Masyarakat Setara. yang berbeda agama dengan agama yang diyakni harus diberikan hak-hak kehidupan secara adil.

Dalam konsep ajaran, mempertahankan keyakinan beragama adalah sah dan menjadi konsekwensi keimanan. Akan tetapi, dalam konteks sekarang, penyantuman konsep perang, jihad, militansi beragama,dan kafir akan sangat mengganggu psikologi siswa. Dengan adanya materi perang sebagai salah satu cara dakwah penyebaran agama, secara tidak langsung akan menggiring siswa pada sebuah pemahaman bahwa perang adalah tindakan yang sah dilakukan untuk menegakkan keyakinan keagamaan. Pemahaman tentang perang tanpa diimbangi dengan penjelasan kultural pada esensi perang yang terjadi pada waktu itu (sejarah) secara detail, akan semakin mengaburkan konsep toleransi (moderat) dan mengarahkan siswa pada pandangan radikal dalam beragama.

Alwi Syihab berpendapat, bahwa untuk bisa tumbuh sikap-sikap menghargai agama kelompok lain dibutuhkan pemahaman keagamaan yang inklusif (terbuka). Sikap inklusif adalah sikap bergama yang mampu menempatan kebenaran agama yang diyakini sebagai keyakinan pribadi yang bersifat mutlak. Akan tetapi, pada sisi lain, keberanan agama yang diyakini itu juga dibarengi dengan sikap menghargai keyakinan keagamaan orang lain. Sikap menghargai dalam beragama ini dalam konsep Islam dikenalkan dalam dalil-dalil qur'an seperti tertera dalam surat ALBaqoroh ayat 256 yang artinya: "Tidak ada paksaan untuk (memasuki) agama Islam; 
sesungguhnya telah jelas jalan yang benar dari pada jalan yang sesat". ${ }^{15}$

Konsep Islam dalam beragama seperti tersebut sangatlah jelas menunjukkan larangan untuk memaksa orang lain dalam beragama. Pemaksaan sebagai bentuk tindakanradikalsangatbertentangandengan prinsip Islam. Konsep bagiku agamaku dan bagimu agamamu adalah bangunan toleransi sebagai bentuk kesepakatan untuk tidak mencampuradukkan ajaran agama, agama yang disembah oleh orang lain adalah hak bagi mereka, dan agama yang disembah oleh orang-orang muslim juga hak bagi orang muslim. Konsep bagimu agamamu dan bagiku agamaku, harus dipahami dalam kerangka teloransi bukan perbedaan.

Sangatlah tepat kiranya, upaya deradikalisasi pendidikan agama melaui kurikulum pendidikan agama mutlak diperlukan. Dalam kurikulum pendidikan dasar memberikan penjelasan mengenai makna surat AlHujurat sangat tepat untuk dikembangkan pada sebagai basis pendidikan Agama di Sekolah Dasar. Dari kedua buku baik penerbit A maupun B telah memuat materi tersebut sebagai materi pendidikan agama kelas 6. Dengan penjelasan makna yang terkandung dalam surat Al-Hujurat ayat 13, akan tertanam nilai untuk membangun kerukunan dalam beragama. Surat AlHujurat ayat 13 , yang artinya berikut:

"wahai manusia! Sungguh, Kami telah menciptakan kamu dari seorang laki-laki dan seorang perempuan, kemudian kami jadikan kamu berbangsa-bangsa dan bersuku-suku agar kamu saling mengenal. Sungguh, yang paling mulia Di antara kamu di sisi Allah ialah

${ }^{15}$ Alwi Shihab. 1997. Islam Inklusif Menuju Sikap Terbuka Dalam Beragama. Bandung: Penerbit Mizan. orang yang paling bertakwa. Sungguh Allah Maha Mengetahui, dan Mahateliti".

Esensi ayat ini yaitu memuat nilai multikultural danteloransi, nilai menghargai perbedaan sebagai manusia yang diciptakan Allah berbangsa-bangsa dan bersuku-suku. Berbedaan adalah sebuah kenyataan alami yang inhern (sunnatullah). Keragamaan harus dipahami sebagai rahmat, bukan sebagai perbedaan yang mendatangkan permusuhan.

\section{KESIMPULAN}

Nilai-nilai moral pendidikan agama Islam yang diterbitkan oleh penerbit $\mathrm{A}$ dan B, berpedoman pada standar isi yang dikeluarkan oleh kementerian pendidikan dan kebudayaan. Nilai-nilai moral secara umum menyangkut aspek aqidah, syariah dan ahlak. Akan tetapi materi-materi terebut secara umum masih membangun kesalehan pribadi semata, belum membangun kesalehan sosial yang sangat dibutuhkan dalam rangka membangun kerukunan dan teloransi beragama.

Dalam buku PAI SD terdapat materi yang mengandung unsur radikalisme dalam beragama dan juga terdapat nilai-nilai moral yang menghargai perbedaan dalam beragama. Materi PAI yang berpotensi dapat menumbuhkan sikap radikal dalam beragama seperti materi yang menjelaskan tentang konsep kafir, kisah militansi beragama, jihad, pertentangan ajaran antar agama, dan kisah-kisah perang pada zaman sahabat. 


\section{SUMBER BACAAN}

Ngatawi, Al-Zasrouw (2006): Gerakan Islam Simbolik: PolitikKepentingan FPI. Yogyakarta, LkiS.

Antoun, Richard T. (2001): Understanding fundamentalism: Christian, Islamic, and Jewish. Walnut Creek. CA, AltaMira Press

Asfar, Muhammad ed. (2003): Islam Lunak Islam Radikal. Surabaya, JP Press.

Cahyono, Nastiti (2015): Ancaman Radikalisme Pada Dinamika Kehidupan Generasi Muda. www.compasiana.com.

Chirzin, M Habib (2005): Penafsiran Rasyid Ridla dan Sayyid Quthb Tentang Jihad. Jakarta, Departemen Agama.

Departemen Pendidikan dan Kebudayaan (1989): Kamus Besar Bahasa Indonesia. Jakarta, Balai Pustaka.

Imarah, Muhammad (1999): Fundamentalisme Dalam Perspektif Barat dan Islam. Terj. Abdul Hayyie al-Kattani. Jakarta, Gema Insani Press.

Khozin, Wahid (2013): “Sikap Keagamaan dan Potensi Radikalisme Agama Mahasiswa Perguruan Tinggi Agama". Edukasi Jurnal Pendidikan Agama dan Keagamaan, 11 (3).

Miun, Abdul.Dkk.(2007): Pendidikan Pesantren dan Potensi Radikalisme. Jakarta, CV. Prasasti.

Mun'in, A. (2003): Membendung Militansi Agama: Iman dan Politik Dalam Masyarakat Modern. Jakarta, Erlangga.
Purwanto, Ngalim. (2003): Ilmu Pendidikan Teoretis dan Praktis. Bandung, PT Remaja Rosdakarya.

Qodir, Zuly. (2014): Radikalisme Agama di Indonesia. Yogyakarta, Pustaka Pelajar.

Shihab, Alwi. (1997): Islam Inklusif Menuju Sikap Terbuka Dalam Beragama. Bandung, Penerbit Mizan.

Tim Setara Institut. (2012): Dari Radikalisme Menuju Terorisme: Studi Relasi dan Transformasi Organisasi Islam Radikal di Jawa Tengah dan D.I. Yigyakarta. Jakarta, Pustaka Masyarakat Setara.

Tim Setara Intitute. (2010): Wajah Para "Pembela" Islam: Radikalisme Agama dan Implikasinya terhadap Jaminan Kebebasan Beragama/Bekeyakinan di Dejabotek dan jawa Barat. Jakarta, Pustaka Masyarakat Setara.

Turmudzi, Endang dan Riza Sihbudi. (2005): Islam dan Radikalisme di Indonesia. Jakarta, LIPI Press.

Voaindonesia. (2012): KPAI Desak Pemerintah Atasi Radikalisme Agama. www. voaindonesia.com.

Yusuf Al-Qordawi (2001): Ekstrimisme Dalam Wacana Islam, Islam Liberal, Pemikiran Islam Kontemporer Tentang Isu-Isu Global. Charles Khurzman (ed): Jakarta, Paramadina.

Zada, Hamami (2004): Islam Radikal: Pegulatan Ormas-Ormas Islam Garis Keras di Indonesia. Jakarta, Teraju. 